\title{
Patterns of exotic species richness of different taxonomic groups in a fragmented landscape of central Chile
}

\author{
Patrones de riqueza de especies exóticas de diferentes grupos taxonómicos en un paisaje \\ fragmentado de Chile central
}

\author{
Pablo I Becerra ${ }^{a *}$, Javier A Simonetti ${ }^{\mathrm{b}}$

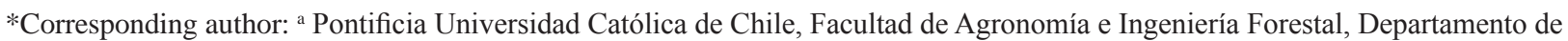 \\ Ecosistemas y Medio Ambiente, Av. Vicuña Mackenna 4860, Santiago, Chile, tel.: 56-2-26865708, fax: 6864169, pablobecerra@uc.cl \\ ${ }^{\mathrm{b}}$ Departamento de Ciencias Ecológicas, Facultad de Ciencias, Universidad de Chile, Las Palmeras 3425, \\ Casilla 653, Santiago, Chile, jsimonet@uchile.cl
}

\begin{abstract}
SUMMARY
Despite many studies have documented that fragmentation facilitates biological invasions, studies performed in different taxonomic groups have observed contrasting patterns. Unfortunately, the use of different ecosystems and fragmentation metrics among studies does not allow assessing the generality of the effect of fragmentation on invasion among different taxa. Studies evaluating the simultaneous responses of exotic species from different taxonomic groups to the same fragmentation patterns may help to assess generality of this relationship. Temperate forests in coastal central Chile are largely a suite of fragments of different sizes surrounded mainly (but not exclusively) by Pinus radiata plantations. Here, we evaluated exotic species richness of vascular plants, insects, mammals and birds in the coastal Maulino forest in a continuous native forest, fragments of native forest and Pinus radiata plantations. Species richness of exotic species of all taxa varied similarly across landscape units. Plantations presented the highest number of exotic species, followed by fragments and finally the continuous forest. In addition, regarding all exotic species, landscape units showed a nested pattern in which most exotic species present in the continuous forest were also present in fragments; and most species present in fragments were present in the pine plantation as well. Our results suggest that fragmentation may affect invasion of different taxa in a similar way, and that continuous forests may efficiently resist invasion. Our results also suggest that given that most of the native forest of south-central Chile is distributed in small fragments, it seems urgent to start an exotic species control to maintain their conservation value.
\end{abstract}

Key words: exotic plants, exotic mammals, exotic insects, exotic birds, fragmentation.

\section{RESUMEN}

A pesar de que varios estudios han observado que la fragmentación del hábitat facilita la invasión de especies exóticas, trabajos realizados en distintos taxa han observado patrones diferentes. Lamentablemente, el uso de diferentes tipos de ecosistemas y métricas de fragmentación no permite establecer la generalidad del efecto de la fragmentación en la invasión de diferentes taxa. Estudios que evalúen simultáneamente la respuesta de especies exóticas de diferentes grupos taxonómicos a los mismos patrones de fragmentación podrían ayudar a establecer la generalidad de esta relación. El bosque templado de la zona costera de Chile central está compuesto de fragmentos de diferentes tamaños rodeados principalmente (pero no exclusivamente) por plantaciones de Pinus radiata. En este trabajo se evaluó la riqueza de especies exóticas de plantas, insectos, mamíferos y aves en un bosque nativo continuo, fragmentos de bosque nativo y plantaciones de Pinus radiata. La variación de la riqueza de especies exóticas entre las unidades de paisaje fue similar entre los taxa estudiados. Las plantaciones presentaron más especies exóticas, seguido por fragmentos y, finalmente, el bosque continuo. La composición de especies exóticas presentó un patrón anidado entre las unidades de paisaje: la mayoría de las especies exóticas presentes en el bosque continuo estuvieron en los fragmentos, y la mayoría de las especies de los fragmentos estuvieron en la plantación. Los resultados sugieren que la fragmentación puede afectar la invasión de diferentes taxa similarmente, y que el bosque continuo puede resistir eficientemente la invasión. Los resultados también sugieren que debido al estado fragmentado de estos bosques nativos de Chile, parece urgente un control de especies exóticas para mantener su valor de conservación.

Palabras clave: plantas exóticas, mamíferos exóticos, insectos exóticos, aves exóticas, fragmentación.

\section{INTRODUCTION}

Invasion by exotic species is currently a relevant issue in ecology and a global concern for conservation biology. Then, getting knowledge on factors driving invasion appears as highly relevant when planning management, con- servation and restoration actions. One of the most common tenets in invasion ecology is that disturbance promotes invasion by exotic species (D’Antonio et al. 1999). Habitat fragmentation due to changes in land use is one of the most detrimental disturbances for biodiversity (Saunders et al. 1991) and it has been frequently correlated 
positively to invasion by exotic species in different taxa (Saunders et al. 1991, Brothers and Spingarn 1991, Hobbs 2001, With 2001). For instance, abiotic changes such as increases in light, temperature and wind velocity and reductions in moisture with forest fragmentation (Saunders et al. 1991, Didham and Lawton 1999) may favor species frequently inhabiting open habitats; many of them exotics. In addition, small fragments are usually surrounded by agricultural fields, plantations, roads and other land uses, and hence closer to ruderal habitats from where exotic species may access (Hobbs 2001, With 2001). Thus, invasion of exotic species into fragments or continuous habitats occurs from the anthropogenic matrix surrounding native habitats (With 2001). This frequently produces that species invading continuous habitats are a subset of the species invading fragments, and all these species a subset of exotic species present in the matrix, determining a nested distribution of exotic species across the landscape (e.g. Leprieur et al. 2009). By contrast, other studies have documented no significant or even negative relationships between fragmentation and invasion by exotic species (e.g. Teo et al. 2003). Additionally, although many studies have assessed the relationship between fragmentation and plant invasion (e.g. Brothers and Spingarn 1991, With 2001, Teo et al. 2003), very few studies have examined this issue in animals (e.g. Hobbs 2001). Furthermore, different studies about this concern usually differ in the ecosystem type and fragmentation metrics. Thus, it is difficult to establish how general the effect of fragmentation on invasion of different taxonomic groups is. Hence, assessing the effect of fragmentation on different taxa under the same ecosystem conditions may be crucial to examine generality of its role for biological invasions among different organisms.

Temperate forests of south-central Chile hold a rich and endemic biodiversity (San Martín and Donoso 1996) but have been replaced and fragmented by different land uses, and more recently by commercial plantations of Pinus radiata D. Don. (Bustamante and Castor 1998, Echeverría et al. 2006). Currently, coastal Maulino forests comprise mainly small remnant fragments, although some less disturbed and larger fragments are still present, mostly as protected areas (Bustamante and Castor 1998). One of these protected areas is Los Queules National Reserve; a 145 ha protected area, immersed within a larger tract of approximately 600 ha of native forest. This continuous forest is surrounded by $P$. radiata plantations and scattered remnants of the original forest. These fragments are of conservation value due to their high levels of native biodiversity, presence of endemic and endangered native species (Bustamante and Castor 1998, Echeverría et al. 2006, Simonetti et al. 2006). However, despite the relevance to the conservation of the native biota of this endangered forest, the magnitude of invasions and potential threats posed by different exotic taxa has not been assessed at landscape level.

In Chile, research on biological invasions has increased significantly during the last years; however, until the moment it is unknown if there are some generalities in the invasion patterns among taxa (Quiroz et al. 2009). In this framework, we assessed whether invasion by exotic species is related to fragmentation and if it depends on the taxonomic group. To do this we analyzed the species richness and composition of exotic vascular plants, insects, mammals and birds in commercial P. radiata plantations, forest fragments, and a continuous forest (Los Queules National Reserve). We expect a larger proportion of exotic species in the $P$. radiata plantation, followed by the fragments; our lower expectancy being in the continuous forest. In addition, species composition of exotic species in the continuous forest should be nested in the other two landscape units, and fragments should be nested in the $P$. radiata plantation. We also expect a similar response to fragmentation by all the taxonomic groups.

\section{METHODS}

Study area. The study site is located in the coastal area of the Maule region, central Chile ( $\left.35^{\circ} 59^{\prime} \mathrm{S}, 72^{\circ} 41^{\prime} \mathrm{W}\right)$, and comprises the Trehualemu Priority Site for Biodiversity Conservation (figure 1). Landscape units are: a) one continuous non-disturbed native forest (Los Queules National Reserve and the forest tract in which it is located), b) four forest fragments and c) the matrix of Pinus radiata plantations surrounding the fragments and continuous forest (figure 1). Native forests are a mix of deciduous and evergreen species, dominated by Nothofagus glauca (Phil.) Krasser and N. obliqua (Mirb.) Oerst., Cryptocarya alba (Mol.) Looser, Luma apiculata (DC) Burret, Aextoxicon punctatum R. et P., and Gevuina avellana Mol. Pinus radiata plantations are harvested every $15-20$ years, and immediately re-planted. This study compiled data recorded during the period in which Pinus radiata plantations adjacent to the continuous forest and fragments were between 15-20 years old. Similarly, native forests used in this study were not altered during the period in which data were recorded.

Source of information. We compiled information about species composition (native and exotic) from vascular plants, coleopterous insects, folivorous insects, small mammals and birds from published and unpublished studies of the area. Plant data corresponded to original data gathered in 30 plots of $100 \mathrm{~m}^{2}$, systematically located every $10 \mathrm{~m}$ in each landscape unit (10 plots per unit type). Sampling was performed during spring-summer of 2004 - 2005. Information about coleopterous insects was obtained from Grez et al. (2003), who registered species in 180 Barber traps (60 per landscape unit) during spring-summer of 2000. Data on folivorous insects were obtained from De la Vega and Grez (2008), who sampled species composition of defoliating insects during spring-summer of 2005 2006, in 64 trees located in the continuous forest and forest fragments (Pinus radiata plantation was not sampled for 


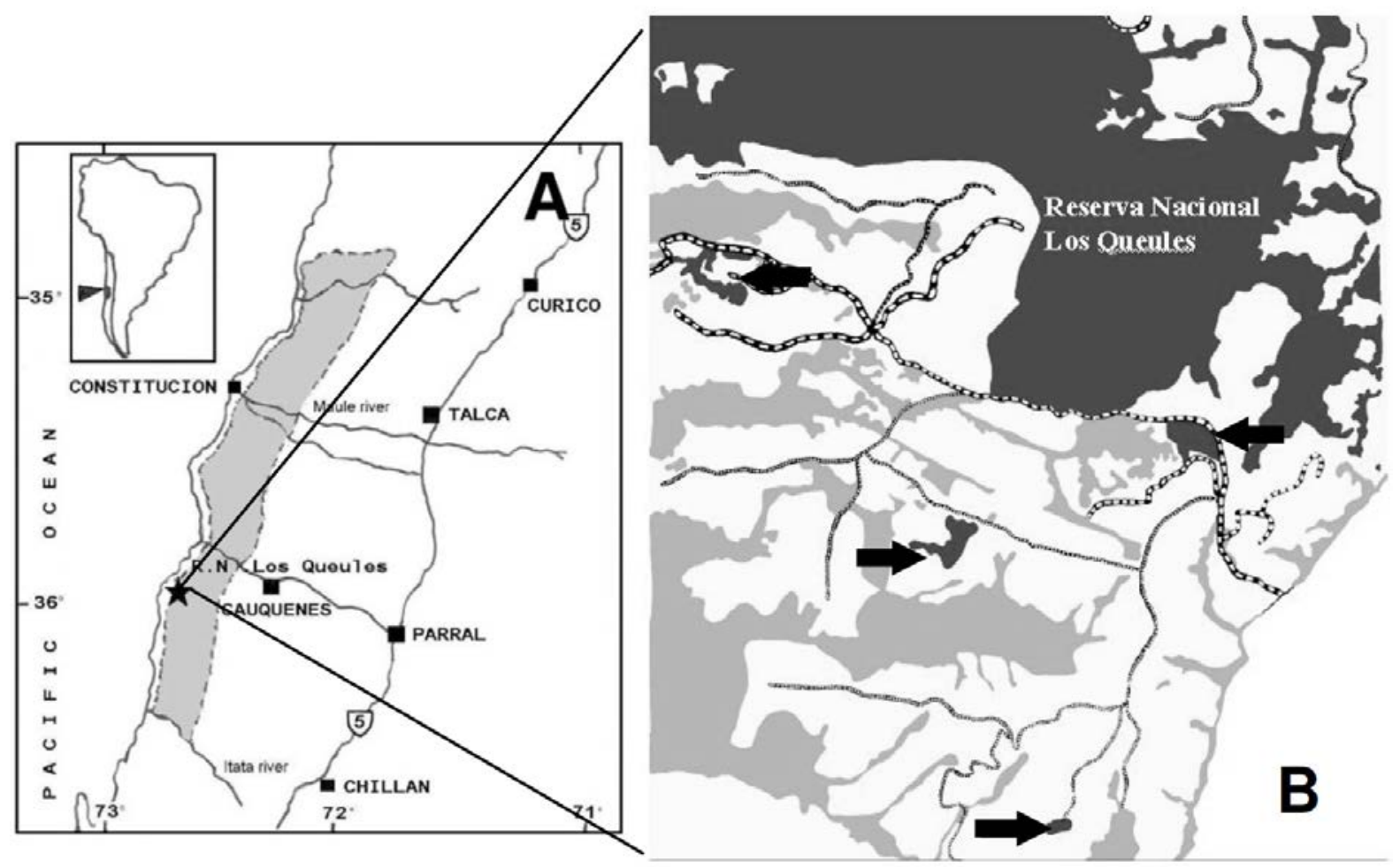

Figure 1. A) Geographical distribution of the Maulino forest (gray) and location of Reserva Nacional Los Queules (modified from San Martín and Donoso 1996). B) Study site showing the continuous forest (dark gray) and adjacent fragments used in the study (dark gray indicated with arrows). Other patches of native forest are shown in light gray and matrix of pine plantations are in white.

A) Distribución geográfica del bosque Maulino (gris) y ubicación de la Reserva Nacional Los Queules (modificado de San Martín y Donoso 1996). B) Sitio de estudio mostrando el bosque continuo (gris oscuro) y fragmentos adyacentes usados en el estudio (gris oscuro indicados con flechas). Otros fragmentos de bosque nativo son mostrados en gris claro y la matriz de plantación de pinos en blanco.

this group). Information on Apoideans was obtained from Valdovinos et al. (2009), who sampled species richness in 40 interception traps from 2003 to 2006. Information on birds was obtained from Vergara and Simonetti (2004), who registered bird species in 50 circular plots $(11$ in the continuous forest, 11 in the forest fragments and 28 in the plantation matrix). Finally, information on small mammals was obtained from Saavedra and Simonetti (2005), who used live-traps with a trapping effort of 8,789 traps per night (3,909 in the continuous forest, 2,056 in forest fragments and 2,822 in the matrix).

All these studies were carried out in the same fragments, continuous forest and Pinus radiata plantations. In addition, there was no change in cover and height of the vegetation (plantations and native forests) in the study area during the data collection period in these studies. This allowed us to compare studies carried out in different years.

Analysis. We considered the relative richness of exotic species in every taxonomic group (percentage of exotic species from the total number of species) in each landscape unit as an estimate of the invasion level. To graphically describe variation of exotic species richness between pairs of landscape units, we plotted relative species richness in a given landscape unit against relative species richness in another unit. The points on the diagonal represent equal relative species richness between the two sites. To statistically compare relative exotic species richness of every taxonomic group between two landscape units, we used two-tailed proportion tests. Finally, we evaluated nesting among landscape units according to Atmar and Patterson (1995). This procedure evaluates the order and disorder of the distribution pattern of species through the landscape by Temperature Analyses, which allows establishing whether there is some general pattern among locations in the landscape, either nestedness or checkboard (Atmar and Patterson 1995). Temperature analyses were carried out according to the Nestedness Temperature Calculator program (Atmar and Patterson 1995), in which an observed temperature value $(T)$ is obtained and compared to randomly determined $T$ values by a Monte Carlo simulation process. Significantly lower values of $T$ than those expected by chance indicate nestedness and significantly higher $T$ values than those expected by chance indicate a checkboard pattern (Atmar and Patterson 1995). 


\section{RESULTS}

Taxonomic composition of exotic species in the landscape. At the landscape level, exotic plants comprised 16 species, largely Poaceae (25\%) and Rosaceae (19\%), accounting for $16.8 \%$ of the total number of plant species in the study area (table 1). Three species of exotic coleopterous insects were found (two Curculionidae, one Coccinelidae), accounting for $0.89 \%$ of total species of ground-dwelling coleopterans (table 1). Only one exotic species of small mammals was registered, accounting for $11.1 \%$ of the total small mammals species found in the area (table 1). Similarly, one exotic bird species was recorded, representing $3.1 \%$ of the total bird species found (table 1). There was not exotic species recorded among the 890 individuals collected of folivorous insects. Similarly, no exotic apoidean species were recorded, at least when forestry plantations were standing.
Variation of exotic species richness and composition among landscape units. Overall, in plantations there were 19 exotic species; 3.2 times more species than in the continuous forest, which had six exotic species, mainly vascular plants (table 1). In forest fragments there were 14 exotic species; that is, 2.3 times more than in the continuous forest (table 1). Furthermore, species composition was significantly nested among landscape units, with plantations holding all but one exotic species present in forest fragments which in turn holds all but one species recorded in the continuous forests $(P(T<11.24)=0.03)$.

In plants, relative richness of exotic species was higher in the plantation ( 15 species, $28.3 \%$ ), followed by the fragments (10 species, $15.6 \%$ ) and the lowest in the continuous forest (4 species, $6.5 \%$ ). The proportion of exotic species did not differ between the continuous forest and the fragments ( $P=0.11$; figure $2 \mathrm{~A})$, but exotics are proportionally higher in plantations than in the continuous forest

Table 1. Presence of exotic species per taxonomic group among landscape units. Folivorous insects and Apoideae are not indicated because there was not exotic species observed in the landscape units.

Presencia de especies exóticas por grupo taxonómico entre las unidades de paisaje. Insectos folívoros y Apoideae no son indicadas ya que no se observaron especies exóticas de estos grupos en las unidades de paisaje.

\begin{tabular}{|c|c|c|c|}
\hline Species & Continuous forest & Fragments & Plantation \\
\hline \multicolumn{4}{|l|}{ Vascular plants } \\
\hline Agrostis capillaris L. & $\mathrm{X}$ & $\mathrm{X}$ & $\mathrm{X}$ \\
\hline Cynosorus echinatus L. & - & $\mathrm{X}$ & $\mathrm{X}$ \\
\hline Digitalis purpurea L. & $\mathrm{X}$ & - & - \\
\hline Gastridium ventricosum (Gouan) Schinz et Thell. & - & $\mathrm{X}$ & $\mathrm{X}$ \\
\hline Holcus lanatus L. & - & - & $\mathrm{X}$ \\
\hline Hypericum perforatum L. & - & $\mathrm{X}$ & $\mathrm{X}$ \\
\hline Hypochoeris radicata $\mathrm{L}$. & - & - & $\mathrm{X}$ \\
\hline Lactuca virosa $\mathrm{L}$. & - & $\mathrm{X}$ & $\mathrm{X}$ \\
\hline Plantago lanceolata L. & - & $\mathrm{X}$ & $\mathrm{X}$ \\
\hline Prunella vulgaris L. & - & - & $\mathrm{X}$ \\
\hline Rumex acetosella L. & - & - & $\mathrm{X}$ \\
\hline Sanguisorba minor Scop. & - & - & $\mathrm{X}$ \\
\hline Pinus radiata D. Don & - & $\mathrm{X}$ & $\mathrm{X}$ \\
\hline Rosa moschata Herrm. & - & $X$ & $\mathrm{X}$ \\
\hline Rubus ulmifolius Schott. & $\mathrm{X}$ & $\mathrm{X}$ & $\mathrm{X}$ \\
\hline Teline monspessulana (L.) K. Koch & $\mathrm{X}$ & $\mathrm{X}$ & $\mathrm{X}$ \\
\hline \multicolumn{4}{|l|}{ Coleopterous insects } \\
\hline Hippodamia convergens Guerin-Meneville & - & $\mathrm{X}$ & - \\
\hline Hylaster ater (Paykull) & $\mathrm{X}$ & $\mathrm{X}$ & $\mathrm{X}$ \\
\hline Hylurgus ligniperda (Fabricius) & - & - & $\mathrm{X}$ \\
\hline \multicolumn{4}{|l|}{ Birds } \\
\hline Callipepla californica (Shaw) & - & $\mathrm{X}$ & $\mathrm{X}$ \\
\hline \multicolumn{4}{|l|}{ Small mammals } \\
\hline Rattus rattus (Linnaeus) & $\mathrm{X}$ & $\mathrm{X}$ & $\mathrm{X}$ \\
\hline
\end{tabular}


$(P=0.002$; figure $2 \mathrm{~B})$, and marginally higher in the plantations than in the fragments $(P=0.09$; figure $2 \mathrm{C})$. In small mammals, the relative species richness was not statistically different among the landscape units studied (plantation: $16.7 \%$, fragments: $12.5 \%$ and continuous forest: $11.1 \%$; $P=0.76$ in all the comparisons; figure 2). There was not exotic bird species recorded in the continuous forest, and the relative species richness was similar in the plantation (3.5 \%) and fragments (3.6 \%; $P=0.35$; figure 2). Among coleopterans, the plantation presented the highest relative richness $(1.38 \%)$, followed by fragments $(0.89 \%)$ and the continuous forest $(0.49 \%)$. All comparisons differed statistically $(P<0.001)$ (figures $2 \mathrm{~A}, 2 \mathrm{~B}, 2 \mathrm{C})$.
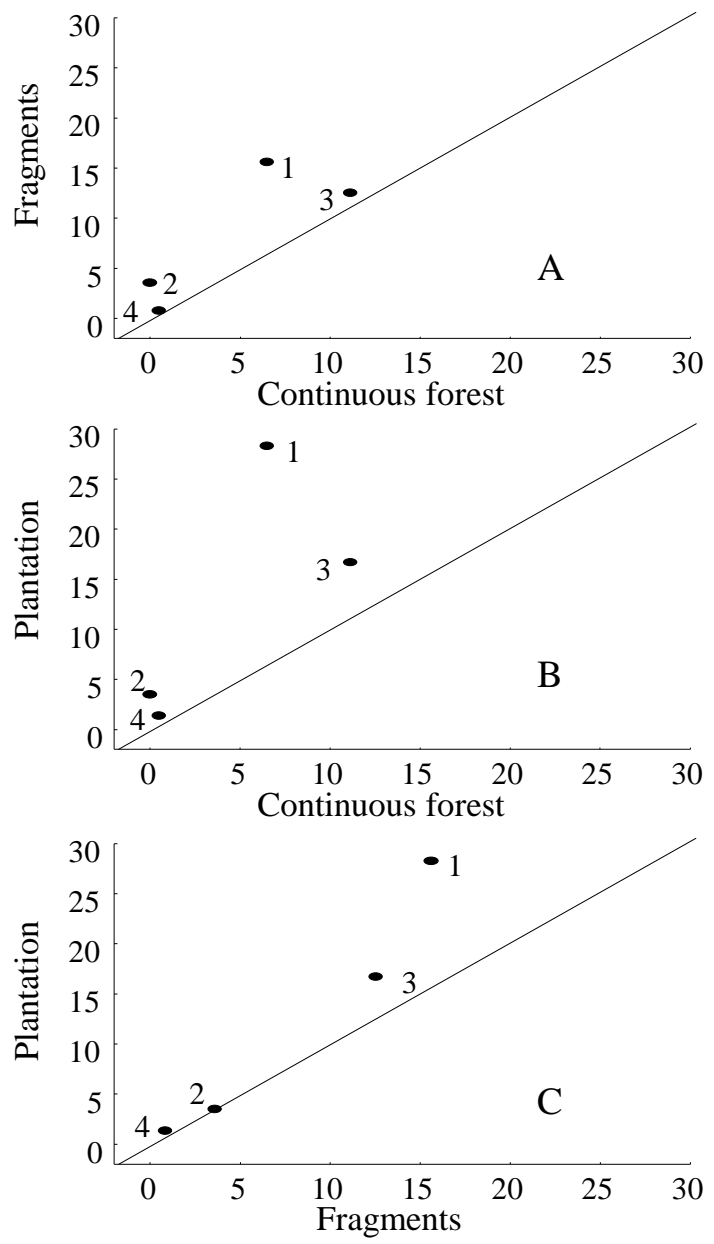

Figure 2. Comparison of the relative species richness (exotic species from the total number of species) per taxonomic group between landscape units: A) between continuous forest and fragments, B) between continuous forest and plantation, C) between fragments and plantation (1: vascular plants, 2: birds, 3: small mammals, 4: coleopterous insects). Diagonal line indicates points with equal relative species richness of exotic species.

Comparación de la riqueza relativa de especies exóticas por grupo taxonómico entre unidades de paisaje: A) entre el bosque continuo y fragmentos, B) entre el bosque continuo y la plantación, C) entre fragmentos y plantación (1: plantas vasculares, 2: aves, 3 : mamíferos pequeños, 4: insectos coleópteros). La diagonal indica los puntos con igual riqueza relativa de especies exóticas.

\section{DISCUSSION}

At landscape level, invasion by exotic species is a spatially heterogeneous phenomenon (Brothers and Spingarn 1991, With 2001). Invasion at the coastal Maulino forest is not the exception; exotic species richness differed among the matrix of pine plantations, fragments and the continuous forest in all taxonomic groups. However, in contrast to our initial hypothesis, the relationship between invasion and fragmentation was not equal among taxa. We observed that four of the six taxonomic groups included in this study presented exotic species in the study area. In three of them (plants, coleopterans and birds) we observed greater exotic species richness in fragments and the pine plantation than in the continuous forest. Instead, in mammals, invasion was not significantly different among landscape units, although even in this group relative richness of exotic species showed the same tendency than that shown by the other taxa. Thus, in spite of these differences in statistical results among taxa, we observed that in general fragmentation seems to affect positively invasion by exotic species of different taxonomic groups, producing a significant nesting in exotic species composition among landscape units, being the continuous forest a subset of fragments and fragments a subset of the Pinus radiata plantation.

Changes in land use and fragmentation produce important modifications in environmental conditions (Saunders et al. 1991). Replacement of native forest by forest plantation implicates strong environmental changes, especially after logging when the management regime is through clear-cutting or strong reduction in tree cover and density. In remnant native forest fragments, environmental conditions are also quite different when contrasted to those from continuous forests. For instance, air temperature is higher, soil moisture is lower, and light intensity is higher in fragments than in continuous forests (Didham and Lawton 1999). Furthermore, cover of woody species is frequently greater in continuous forests than in fragments (Didham and Lawton 1999) and in native forests than in plantations (Gilliam et al. 1995). Thus, probably these environmental changes caused greater invasion in fragments and in the plantation area, particularly due to lower competition with natives or improving abiotic conditions for exotic species, frequently adapted to open habitats (D'Antonio et al. 1999). For instance, invasion by Pinus radiata, a putative highly invasive species because of the large propagule source surrounding native vegetation, is constrained, probably due to light limitations, even inside forest fragments if canopy remains unaltered (Bustamante and Simonetti 2005). Probably the same mechanism is acting against invasion by the exotic plant Teline montpessulana into native forests of this area (e.g. Pauchard et al. 2008). Likewise, a dense understory might preclude the invasiveness by the exotic bird Callipepla californica in the continuous forest, which usually prefers open vegetation (Estades and Temple 1999). Paradoxically, maintenance of 
dense vegetation might favor the presence of $R$. rattus, a murid that prefers dense and humid habitats to prey upon ground nesting birds (Simonetti 1983). On the other hand, interestingly, standing plantations might hamper the invasion into the native forest by the honeybee Apis mellifera, a harmful species for the effective pollination of native plants (Goulson 2003), which appeared in our forest fragments only after plantations were harvested (Valdovinos et al. 2009). Clearly, to manage forest fragments in order to conserve them as biodiversity reservoirs will require tackling these trade-offs.

The nested pattern observed among the landscape units suggests that plantations might be acting as foci for invasive species and that invasion into fragments and the continuous forest is not a random process. In fact, Hylaster ater, an insect typically pest of Pinus radiata plantations is also invading native vegetation (Grez et al. 2003). Nonetheless, invasion by exotic species may also be triggered from other disturbed sites such as roads (With 2001).

Pine plantations of this area may hold many native species and even act as biological corridors between fragments of native forests (Simonetti 2006); however, they are also the landscape unit with greater richness of exotic species in this area, probably because of the management regime. Nevertheless, pine plantations probably hold lower richness of exotic species than that held by open degraded habitats and roads. It is noteworthy that the continuous forest, a national reserve, is still scarcely invaded, reinforcing the claim that protection against large disturbances would reinforce resistance to invasion (Saunders et al. 1991, D'Antonio 1999). In contrast, despite remnant forest fragments are considered significant reservoirs of native biodiversity (Simonetti 2006), the fact that these fragments present potentially invasive exotic species belonging to different taxonomic groups may threaten conservation of their biodiversity. In consequence, because most of the coastal native forests in south-central Chile are distributed into small fragments, it seems urgent to start an exotic species control in them to maintain their conservation value.

\section{ACKNOWLEDGEMENTS}

Field work as well as the studies from which information was gathered was financed by Fondecyt 1010802 and 1050745. The first author was a Doctoral fellow from Conicyt at the time of data collection and analyses.

\section{REFERENCES}

Atmar W, BD Patterson. 1995. The nestedness temperature calculator: a visual basic program, including 294 presenceabsence matrices. AICS Research, Inc., University Park, NM, and The Field Museum, Chicago. Consultado 1 Ago. 2012. Disponible en http://aics-research.com/nestedness/ tempcalc.html

Brothers T, A Spingarn. 1991. Forest fragmentation and alien plant invasion of central Indiana old-growth forests. Conservation Biology 6: 91-100.

Bustamante R, C Castor. 1998. The decline of an endangered temperate ecosystem: the ruil (Nothofagus alessandrii) forest in central Chile. Biodiversity and Conservation 7: 1607-1626.

Bustamante RO, JA Simonetti. 2005. Is Pinus radiata invading the native vegetation in central Chile?, demographic responses in a fragmented forest. Biological Invasions 7: 243-249.

D'Antonio CM, TL Dudley, M Mack. 1999. Disturbance and biological invasions: direct effects and feedbacks. In Walker LR ed. Ecosystems of disturbed ground. Amsterdam, the Netherlands. Elsevier. p. 413-452.

Didham R, J Lawton. 1999. Edge structure determines the magnitude of changes in microclimate and vegetation structure in tropical forest fragments. Biotropica 31: 17-30.

De La Vega X, AA Grez. 2008. Efecto de la fragmentación del bosque Maulino en la composición, riqueza de especies y abundancia de insectos defoliadores asociada a Aristotelia chilensis. Revista Chilena de Historia Natural 81: 221-238.

Echeverría C, DA Coomes, J Salas, JM Rey Benayas, A Lara, AC Newton. 2006. Rapid deforestation and fragmentation of Chilean temperate forests. Biological Conservation 130: 481-494.

Estades CF, SA Temple. 1999. Deciduous-forest bird communities in a fragmented landscape dominated by alien pine plantations. Ecological Applications 9: 573-585.

Gilliam F, N Turrill, M Adams. 1995. Herbaceous-layer and overstory species on clear-cut and mature central Appalachian hardwood forests. Ecological Applications 5: 947-955.

Goulson D. 2003. Effects of introduced bees on native ecosystems. Annual Review of Ecology, Evolution and Systematic 34: 1-26.

Grez AA, PO Moreno, M Elgueta. 2003. Coleópteros (Insecta, Coleoptera) epigeos asociados al bosque maulino y plantaciones de pino aledañas. Revista Chilena de Entomología 29: 9-18.

Hobbs R. 2001. Synergisms among habitat fragmentation, livestock grazing, and biotic invasions in Southwestern Australia. Conservation Biology 15: 1522-1528.

Leprieur F, JD Olden, S Lek, S Brosse. 2009. Contrasting patterns and mechanisms of spatial turnover for native and exotic freshwater fish in Europe. Journal of Biogeography 36: 1899-1912.

Pauchard A, RA García, E Peña, C Gonzalez, LA Cavieres, RO Bustamante. 2008. Positive feedbacks between plant invasions and fire regimes: Teline monspessulana (L.) K. Koch (Fabaceae) in central Chile. Biological Invasions 10: 547-553.

Quiroz CL, A Pauchard, L Cavieres, CB Anderson. 2009. Análisis cuantitativo de la investigación en invasiones biológicas en Chile: tendencias y desafíos. Revista Chilena de Historia Natural 82: 497-505.

Saavedra B, JA Simonetti. 2005. Small mammals of Maulino forest remnants, a vanishing ecosystem of south-central Chile. Mammalia 69: 337-348.

San Martín J, C Donoso. 1996. Estructura florística e impacto antrópico en el bosque maulino de Chile. In Armesto J, C Villagrán, MTK Arroyo eds. Ecología de los bosques nativos de Chile. Santiago, Chile. Editorial Universitaria. p. 153-168.

Saunders D, R Hobbs, C Margules. 1991. Biological consequen- 
ces of ecosystem fragmentation: a review. Conservation Biology 5: 18-31.

Simonetti JA. 1983. Ocurrence of the black rat (Rattus rattus) in central Chile. Mammalia 47: 131-132.

Simonetti JA. 2006. Conservación de la biodiversidad en ambientes fragmentados: el caso del bosque maulino. In Grez AA, JA Simonetti, RO Bustamante eds. Biodiversidad en ambientes fragmentados de Chile: patrones y procesos a diferentes escalas. Santiago, Chile. Editorial Universitaria. p. 215-231.

Teo D, H Tan, R Corlett, C Min Wong, S Lum. 2003. Continental rain forest fragments in Singapore resist invasion by alien plants. Journal of Biogeography 30: 305-310.

Valdovinos FS, E Chiappa, JA Simonetti. 2009. Nestedness of bee assemblages in an endemic South American forest: the role of pine matrix and small fragments. Journal of Insect Conservation 13: 449-452.

Vergara PM, Simonetti JA. 2004. Avian responses to fragmentation of the Maulino forests in central Chile. Oryx 38: 383388.

With K. 2001. The landscape ecology of invasive spread. Conservation Biology 16: 1192-1203.

Recibido: 27.10 .11

Aceptado: 29.08.12 
